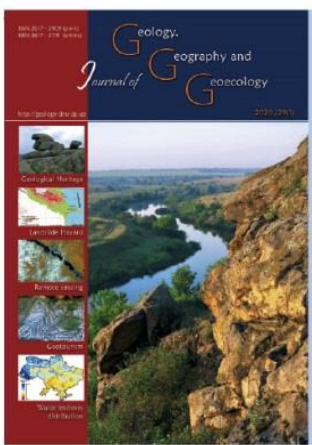

Journal of Geology, Geography and

Journ.Geol.Geograph. Geology, 29(1), 30-39.

Journal home page: geology-dnu-dp.ua doi: $10.15421 / 112003$

Yaroslav M. Bilanchyn, Iryna V. Leonidova, Darya V. Bulysheva Journ.Geol.Geograph.Geoecology,29(1),30-39.

\title{
Specificity of genetic nature and classification characteristics of Zmiiny Island chernozem soils
}

\author{
Yaroslav M. Bilanchyn ${ }^{1}$, Iryna V. Leonidova², Darya V. Bulysheva \\ ${ }^{1}$ Odessa Mechnikov National University, Odessa, Ukraine \\ ${ }^{2}$ Odessa State Agrarian University, Odessa, Ukraine, leonidova999@ gmail.com
}

Received:03.08.2019

Received in revised form: 10.09 .2019

Accepted: 26.01.2020

Abstract. Even the first researchers of the nature of the small (20.5 hectares) rocky Zmiiny Island in the northwestern Black Sea region visually diagnosed the soil there with black earth. Since 2003, the staff of the Department of Soil Science and Soil Geography of the Odessa National University named by I.U.Mechnikov ONU began the study of factors and processes of soil formation, soils and soil cover of Zmiiny Island territory. It was found out that on the inter-rocky areas of the island under the steppe grassy vegetation on the gravelly-stony eluvium or eluvium-deluvium of dense rocks formed unusually high humus (up to 14-18\%) undeveloped and short-profile chernozem soils. However, the diagnostic and classification of these soils remains unclear. The purpose is to characterize the specificity of the genetic nature of the island soils and to determine their diagnostic and classification affiliation, including the World Reference Base for Soil Resources WRB.The materials presented in this article are obtained as a result of our extensive fieldwork and laboratory analysis, research and mapping of soils and soil cover of Zmiiny Island with the application of methodological principles of the process-genetic paradigm.Chernozem soils on the island are formed on a low-strength (25-40, up to $50 \mathrm{~cm}$ ) rocky-gravelly crust of weathering of dense acidic rocks under the cover of almost virgin steppe herbaceous vegetation and year-round salting from the sea, mainly chlorides and Na sulfates. The soils are short-profile, typical chernozem humus-accumulative type with typical for the chernozem profile genetic horizons, gravel-stony, non-carbonate, almost non-structural, acidic, varyingly saline and solonetinous, but without solonets-ileuvial profile differentiation. The humus content in the upper horizons is very high (10-12, up to $15-18 \%$ ), it is typical of the chernozem composition of the Chumic acid : Cfulvic acid (2,5-3,3), but with a sharp dominance of the HA-1 fraction (70\% and more) and very low content (1-2, up to 3-4\%) or lack of typical chernozem HA-2fraction. It is established that there is a tendency to an irreversible constant increase of the chernozem properties and characteristics in soils as the bioproductivity of herbal vegetation increases.For the first time their diagnostic and classification dependence on the system of both domestic and World WRB soil classifications has been determined. The WRB system proposes to refer these soils to the Phaeozem abstract group, with clarification of the classifiers Leptic and Skeletic. The work is practically significant in terms of the integration the Ukrainian soil science in the system of the current international standard of soil classification WRB.

Keywords: Zmiiny Island, chernozem soils and their geographic and genetic features, classification characteristics.

\section{Специфічність генетичної природи та класифікаційна належність чорноземних грунтів острова Зміїний}

Я. М. Біланчин ${ }^{1}$, І. В. Леонідова², Д. В. Булишева ${ }^{2}$

${ }^{1}$ Одеський національний університет імені I. I. Мечникова, Одеса, Украӥна

${ }^{2}$ Одеський державний аграрний університет, Oдеса, Україна, leonidova999@gmail.com

Анотація. За результатами багаторічних 2003-2018 рр. грунтово-генетичних досліджень на о. Зміїний схарактеризовано специфічність умов і процесів утворення, морфології, речовинно-хімічного складу і властивостей тамтешніх чорноземних грунтів та тенденцій їхньої сучасної еволюції. Грунти пересічно неповнорозвинені і короткопрофільні з потужністю гумусового горизонту до 25 і 25-45 см відповідно. Сформувались на елювії чи елюво-делювії щільних кислих порід під покривом практично незайманою степової трав'яної рослинністю і цілорічного поступання солей з моря, головно хлоридів і сульфатів Nа. Грунти короткопрофільні, типово чорноземного гумусово-акумулятивного типу з типовими для чорноземного профілю генетичними горизонтами, щебенювато-кам〉янисті, некарбонатні, практично безструктурні, кислі, різною мірою засолені і солонцюваті, однак без солонцево-ілювіальної диференціації профілю. Ступінь насиченості основами у нижніх горизонтах профілю лише 30-40\%, у верхніх горизонтах більше 50\%, що пояснюється максимальним вмістом у верхніх (кореневмісних) горизонтах поглинутих основ, в т.ч. і Кальцію біогенної природи. Дуже високий у верхніх горизонтах вміст гумусу (10-12, до 15-18 \%) типово чорноземного складу СГК: СФГ (2,5-3,3), однак із різким домінуванням фракції ГК-1 (70 \% і більше) і дуже низьким 
вмістом (1-2, до 3-4 \%) чи й відсутністю типово чорноземної фракції ГК-2. Результати дослідження оптичних властивостей гумусових речовин засвідчують доволі високу оптичну щільність гумінових кислот, властиву зазвичай грунтам чорноземного типу. Встановлено тенденцію до наростання потужності профілю чорноземних грунтів острова догори по мірі зростання біопродуктивності трав'яної рослинності. Вперше визначена діагностико-класифікаційна належність грунтів о. Зміїний в системі як вітчизняної, так і Світової WRB грунтових класифікацій. За системою WRB неповнорозвинені та короткопрофільні чорноземні грунти пропонується відносити до реферативної групи Phaeozem з уточненням визначення кваліфікаторами Leptic i Skeletic. Робота практично значима в плані інтеграції української грунтознавчої науки в систему нинішнього міжнародного стандарту класифікацій грунтів WRB.

Ключові слова: острів Зміӥний, чорноземні трунти та їхні географо-генетичні особливості, класифікаційна належність.

Introduction.The first researchers of the nature of Zmiiny Island (also Snake or Serpent Island) - namely, a topographer M. Krytskyi as early as in 1823, and professor of Richelieu Lyceum (Odesa) O. Nordman in 1841 - managed to diagnose visually the local soils as "chernozems" (fertile black soils rich in organic matter). The island soils were also classified as chernozems by the I. I. Mechnikov Odessa National University experts who first investigated the genetic origin, material-and-chemical composition and properties of the island soils in the studies conducted during a period from 2003-2005 to 2016-2018. The research has shown that here, in the inter-rock areas of thin rocky-gravelalluvia or alluvium-deluvium of dense siliceous (acid) rocks beneath the steppe herbaceous vegetation, immature and shallow chernozems with the humus horizon thickness up to $25 \mathrm{~cm}$ and $25-45 \mathrm{~cm}$, respectively, characterised by specific morphological features, composition and properties, have been formed (Bilanchyn et al., 2008; 2009; 2010; Bilanchyn, 2011; Leonidova, 2013; 2017).

Since the research by V.V. Dokuchaev, the formation and distribution of chernozems is commonly associated with luxuriant grassland and steppe herbaceous vegetation of forest-steppe and typical steppe regions, as well as with semi-arid climate and its well-pronounced seasonal contrasts. Carbonate highporous loess, loess-like and light-clay loams tend to be the most common soil-forming (parent) materials here. Intensive mineralisation and humification of the litter of luxuriant herbaceous vegetation and its extensive root system during relatively humid and warm spring and early-summer season are followed by polycondensation, which is further thickening of newly formed humic substances during subsequent hot and dry, as well as freezing weather seasons. It results in the formation of dark-brown to black coloured horizon of humus accumulation with high topsoil content of humus and biophile elements (up to $8-10 \%$ and above), in particular calcium. The lower part of the chernozem profile usually show carbonate accumulation horizons. The upper horizons of chernozems spread over loess can be distinguished by loose configuration and clumpygrained structure, neutral or nearly neutral reaction, high Cation Exchange Capacity (up to 40-50 or even $60 \mathrm{mmol} \cdot \mathrm{eq} / 100 \mathrm{~g}$ ) with dominating absorbed calcium (up to $80-90 \%$ of capacity) and high availability of plant nutrients.

Indeed, the natural environmental conditions on the small Zmiiny island (only 20.5 ha) in the Black Sea are quite peculiar and distinctly different from the conditions of classic chernozem formation. The surface of the island is composed of siliceous (acid) rocks of considerable hardness with very stony-andgravelly thin weathering crusts (usually not thicker than $25-40 \mathrm{~cm}$ ). Hence, the genesis, morphology, material-and-chemical composition and some other properties of the island chernozems can be distinguished by a number of specific features which have been reported in varying detail in our previous publications (Bilanchyn et al., 2008; Bilanchyn, 2011; Leonidova and Bilanchyn, 2017, etc.). Given this, the justification for diagnostics and classification of the island soils as chernozems has been sometimes challenged in the community of Ukrainian soil scientists in recent years. As the current period of the soil science development throughout the world, especially with regard to soil diagnostics and classification, it shows a clear trend towards the adoption of the World Reference Base of Soil Resources - WRB (Charzynski, 2006; Ivanyuk, 2016; Krasilnikov, 2009; Polchina and Nichorich, 2006), the determination of a niche for classification of the Zmiiny Island chernozems within this international classification system was set as one of the objectives of this study.

The issues of diagnostics and classification of soils (in this case chernozem of Zmiiny Island) suggested for consideration and solving in this study remain topical within the framework of the soil science and practice. It was ambition to solve these issues that usually spurred the soil science development heretofore. And the approaches, principles and criteria employed to study, systematise and classify soils still play the pivotal role. Two lines of activity (approaches) still dominate in the international system 
of soil diagnostics and classification; either of them can be used depending on the prioritised principles and criteria of soil diagnostics and classification.

The first approach implies the factor-genetic classification of soils introduced by the founder of pedology, V.V. Dokuchaev (Dokuchaev, 1948). Having defined soil as a natural independent body with a specific origin, history of development and external appearance on the land surface, as well as a product of extremely complex interactions of the effects of natural and economic factors, he reasonably believed that it was certain combinations of these factors that were responsible for the formation of relevant genetic types of soils. In particular, chernozem is a zonal soil type for the steppe zones, though its profile thickness varies with certain changes in weather and climate conditions and with regard to one or another relevant relief feature and type of parent soil. For instance, chernozems spread over loess are thicker than those over eluvium of dense rocks, although the configuration profile of chernozem is typical in both cases.

The second approach is the substantive-genetic classification which has been developed and applied predominantly in foreign soil science and practice, particularly in the WRB classification system. This classification approach is based on the substantivegenetic characteristics of soil, namely diagnostic genetic horizons, their material-and-chemical composition and features, as well as quantitatively defined properties, which results from soil formation under given environmental and ecological conditions, though they may essentially manifest themselves in other biomes.

International cooperation and understanding between soil scientists, as noted above, are impossible without comprehensive system for communication. The World Reference Base for Soil Resources (WRB), which forms the basis for the global level of knowledge generalisation in soil science, is commonly recognised as such a working language for soil classification. The first official version of WRB was released at the $16^{\text {th }}$ World Congress of Soil Science in Montpellier in 1998; the second publication was presented at the $18^{\text {th }}$ World Congress of Soil Science in Philadelphia in 2006, and the third edition of this soil classification (World Reference Base for Soil Resources 2014. International soil classification system for naming soils and creating legends for soil maps, 2014) was published in 2014.

The correlation between national classifications and WRB was the subject of the studies of T.A. Romanova (2004), V.S. Stolbovoy and B.V. Sheremet
(2000), P. Charzynski (2006), S.M. Polchina (2005), M. Polupan et al. (2005) and G.S. Ivanyuk (2016).

In Ukraine, most soil scientists traditionally adopt the factor-genetic approach in soil research, diagnostics and classification. However, in recent decades, they tend to shift from purely factorialgenetic approach to soil diagnostics and classification to increasing involvement of their substantivevisual and analytical characteristics (Ivanyuk, 2017; Krasilnikov, 2009, etc.).

With regard to the above, the aim of our study is to characterise the specificity of the genetic origin of the island soils and determine their diagnostic and classification criteria, including those adopted in the World Reference Database for Soil Resources (WRB). Matherials and methods of research. This paper analyses specificity of the formation of the island chernozem, their specific morphological features, material-and-chemical composition and properties, as well as trends of current evolutionary changes, using methodological principles of process-genetic paradigm and results of many-year soil genetic research carried out since 2003-2005. The data presented in this paper have been obtained from a considerable amount of field and laboratory studies and analytical research, as well as from mapping soils and soil landscapes. It includes studying of environmental and ecological conditions on Zmiiny Island, factors and processes of soil formation, geography of soils, in particular chernozems, their morphological and genetic peculiarities, material-and-chemical composition and properties. The research activities were performed using methods of the field, laboratory and analytical research, as well as mapping of soils involving aerial and space images of landscapes, generally accepted in soil-geographic practice. The main methods of soil genetic studies on the island were comparativegeographical, profile-morphological and comparative morphostructural-analytical.It should be only noted that the survey of the environmental and ecological conditions of the island landscape and chernozems covered nine key localities and six landscape transect profiles (including soil-vegetation-orological ones) on different geomorphologic-gypsometric and exposureslope levels of the surface.

Results and their analysis. Zmiiny Island is the only dome-shaped remnant of a plate of rocks of Paleozoic age in the Black Sea, a plot of natural preserved land for hundreds of thousands of migrating and local birds. The island is formed by dense siliceous (acid) rocks of marked hardness (conglomerates and breccias, quarzites made of metamorphosed quartz arenite, etc.), which crop up widely and cover from 
5-10 to $35-50 \%$ of the territory area, and even more in sloping areas(Manyuk, 2004). The weathering crust of dense rocks tends to be thin (not thicker than 25$40 \mathrm{~cm}$ ) and it is very stony. The island is located in the region experiencing moderate continental climate with long hot summer and short mild winter. The annual precipitation is about $300-350 \mathrm{~mm}$ while evaporation reaches $800-1.000 \mathrm{~mm}$. The east- and south-facing slopes receive $5-10 \%$ to $15-20 \%$ more solar radiation. Hence, the moisture supply in the north- and west-facing hillsides on the island is higher than in the south- and east-facing ones. Almost all year round, mineral salts - mainly, sodium chlorides and sulphates - biophile elements, nitrogen and phosphorus compounds are delivered to the island surface in atmospheric precipitation, as well as harvested from either rock deposits or directly from the sea (Bilanchyn et al., 2013).

Substantially intact steppe vegetation of mixed herbs and grasses covers the surface areas between juts of dense rocks over $75.5 \%$ of the total island area. The total biomass of herbaceous phytocoenosis in the areas of better moisture supply in the west-and north-facing areas of the territory, at flattened bottoms of hills and bottomlands reaches 70-85 t/ha, up to $110 \mathrm{t} / \mathrm{ha}$. However, within the boundaries of $\mathrm{xe}$ romorphic east- and south-facing areas of the territory, it is 3-4 (5) times smaller (Leonidova, 2013). About $60-70 \%$ of the grass biomass is concentrated in the soil turf horizon $\mathrm{Hd}$ and the ground layer of the steppe litter mat Hc.

The bulk mass of grass roots is concentrated in regularly moistened to a mean depth of $15-25 \mathrm{~cm}$ and less stony upper humus accumulation horizon of the $\mathrm{Hq}$ or $\mathrm{H}$ profile. We have established an extremely high ability of the island steppe herbaceous phytocoenosis, in particular their surface organogenic horizon $\mathrm{Hc}+\mathrm{Hd}$ and upper humus-rich horizons of soils, to accumulate an atmospheric moisture which plants use exclusively for the biomass production. The surface runoff, and especially the sub-surface runoff, in the areas with herbaceous vegetation cover is reduced and short-lived, hence the soil erosion processes are less likely to occur here (Leonidova, 2013; Leonidova and Bilanchyn, 2017).

Based on the groundwork laid by V.V. Dokuchaev (1948) onthe chernozem formation theory, as well as on the materials of studyingthe environmental conditions as the factors of soil formation conducted by us, it becomes clear that environmental and ecological conditions of the island are favourable for the formation of soils of this particular chernozemic type. First of all, this means fairly luxuriant steppe herbaceous vegetation beneath which the soil turf horizon $\mathrm{Hd}$ and the ground layer of the steppe litter mat $\mathrm{Hc}$ are formed and wherein $60-70 \%$ of the total biomass is concentrated. After vegetation die-off, considerable amount of its biomass is transformed into humic substances. Every-year seasonal variability in the spring and early-summer period of optimal moisture supply, mineralisation and humification of organic residues; duration of summer and autumn drying-out of soil and diapauses in grass development; coagulation, conservation and accumulation of newly formed humic substances - they all contribute to the humus formation and thickening, as well as formation of chernozems. And as a result of gradually increasing thickness of the surface organogenic horizon $\mathrm{Hd}+\mathrm{Hc}$ beneath substantially intact steppe herbaceous vegetation of the island, the newly formed chernozems also enhance with time (Bilanchyn, 2011; Leonidova, 2017).

At the same time, the results of our investigations indicate a number of specific features of the chernozem formation on the island, primarily associated with peculiarities of the environmental factors of soil formation. The morphology, substance-and-chemical composition and properties of the island soils were defined and are still governed by rather thin stony weathering crust of dense acid rocks. Shallow thickness of the soil-forming substrate is a natural obstacle for the formation of extensive plant root system, and hence soils with thick profiles. Therefore, immature and shallow chernozems with a thickness of humus horizon up to $25 \mathrm{~cm}$ and $25-45 \mathrm{~cm}$, respectively, have been formed on this island (Fig. 1). Such features as gravelly-and-stony profile and acidity which increase towards the lower layers, normally sandy-loam and sandy-granulometric texture of fine-grained soil, the absence of carbonates and base depletion were inherited by the island soils from parental rocks.

The island chernozems are characterised by a quasiuniform-dynamic salinity regime which depends on the weather and climate conditions, as well as on the atmospheric-chemical processes occurring throughout a year. The fraction of readily soluble salts in the surface soil turf horizon $\mathrm{Hd}$ is the most abundant (in average $0.3-0.4 \%$ ) in the soil profile. Apparently, it is not just atmospheric moisture that is accumulated here, but also salts delivered in atmospheric precipitation and directly from the sea. The salinity over the soil profile is quite non-uniform either within the island territory or geomorphic-hypsometric levels of the surface; the most frequently it equals $0.15-0.20$ to $0.30-0.40 \%$.

Unlike chernozems spread over loess in the Southern Ukraine, the island chernozems are poorly 


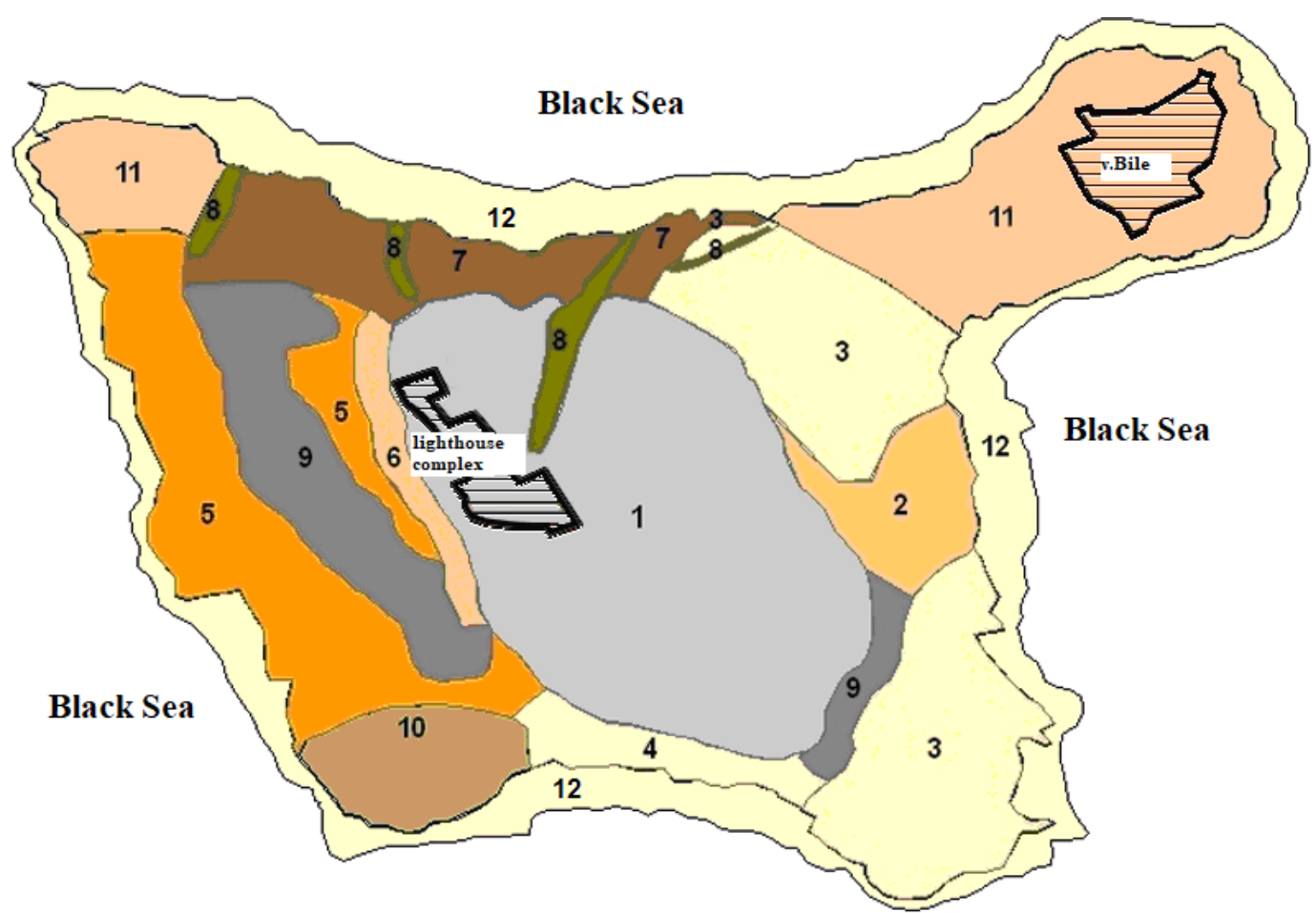

Fig. 1. Diagram map of the Zmiiny island soils

(compliers - Y. M. Bilanchyn, P. I. Zhalatntai, M. I. Tortyk, A. O. Buianovskii, I. V. Leonidova)

Legend

\section{The level (zone) of the vertex-watershed comb-shaped plateau and near-watershed declivous slopes}

1

- Short-profile chornozems in combination with non-fully developed chornozems 30-50\%, and juts of dense rocks and their coarse-grained placers up to $10-20 \%$

The level (zone) of the slopes

2

3

4

5 - Non-fully developed chornozems in combination with short-profile chornozems up to $20 \%$, slightly eroded*, with juts of dense rocks and their coarse-grained placers $10-20 \%$

6 - Non-fully developed chornozems, slightly eroded*, with juts of dense rocks and their coarse-grained placers up to 20-30\% The slopes of the northern exposition

- Short-profile chornozems in combination with non-fully developed chornozems 30-50\%, slightly eroded*, with juts of dense rocks and their coarse-grained placers $20 \%$

- Alluvial meadow chornozems on the bottom of the basins

The level (zone) of deluvial and accumulative areas in the elevation of slopes

Short-profile chornozems in combination with non-fully developed chornozems $10 \%$, and juts of dense rocks and their coarse-grained placers around $10 \%$

The level (zone) of the ancient sea terraces

10 - Short-profile chornozems in combination with non-fully developed chornozems $30-50 \%$, and juts of dense rocks and their coarse-grained placers around $10 \%$

11 - Non-fully developed chornozems with locally weak erosion* and juts of dense rocks and their coarse-grained placers around $30-50 \%$

12 The level (zone) of coastal steep slopes and gorges

- Exits of dense rocks and their coarse-grained placers with fragments of primitive soils on rocky-gravel substrate

* NB: Manifestation of erosion is likely in case of disturbance or erection of the cover of steppe grass vegetation. 
micro-aggregated and practically unstructured. It is likely due to the alkalinity of chernozems and low level of coagulating agents in structural "glues", in particular Ca humate (HA-2 fraction), which plays a critical role in the formation of soil structure and its water-holding capacity (Ponomariova and Plotnikova, 1980).

A specific feature of the physical and chemical characteristics of the island soils is their (high) acidity, which increases downwards in the soil profile. For instance, $\mathrm{pH}_{\mathrm{SOL}}$ of lower horizons of almost all examined cross-sections of the island chernozems is below 4, while hydrolytic acidity reaches 20-30 (and even 35 ) $\mathrm{mmol} \cdot \mathrm{eq} / 100 \mathrm{~g}$ that is only consistent with the relevant values of very acid brownified soils of the Carpathians. The base (alkali) saturation percentage in the lower horizons of the soil profile is just $30-40 \%$ while it is above $50 \%$ in the upper horizons, which can be due to the maximum abundance of the absorbed bases, including calcium which is the most likely of a biogenic origin, in the upper(root-containing) horizons.

The results of the examination of the humus status of the island soils are noteworthy indeed (see the Table below). These results show very high humus content in the upper humus-accumulative horizons (from $10-12$ to $15-18 \%$ ) and downwards in the soil profile (5-8 to $11 \%)$. The total nitrogen level features ubiquitously above $1 \%$ of the total fine-grained soil mass; the humus carbon to nitrogen ratio $\mathrm{C}: \mathrm{N}$ is $7-8$ which is indicative of high humus enrichment with nitrogen. Such unusually high total nitrogen content in the investigated soils is likely to result from advancing accumulation of this element in the biological cycle processes and also from its delivery in the litter of numerous species of the local ornithofauna to the island surface under conditions of low rate of its bioconsumption (Bilanchyn et al., 2008). The humic to fulvic acid ratio $\mathrm{C}_{\mathrm{HA}} / \mathrm{C}_{\mathrm{FA}}$ tends to range within 2.53.3 which is quite typical for the soils of chernozemic type.

Meanwhile, the fractional composition of humus in the specified soils differs markedly from the humus composition in the chernozems spread over loess. In particular, the HA-1 fraction, which consists of free (newly formed) and bound with one and a half oxides of $\mathrm{Fe}$ and $\mathrm{Al}$ brown humic acids, dominates distinctly in the humus composition, making $65-75 \%$ of the total humic acid content in the upper horizons and increasing to $80-84 \%$ downwards in the soil profile. Such abnormally high content of the HA-1 fractionin the island chernozems may be associated with active interaction between the newly-formed humic acids and young oxides of $\mathrm{Fe}$ and $\mathrm{Al}$, which are products of the weathering of acid dense rocks of the soil mineral base (Bilanchyn et al.,2009). It is the most likely that the afore-described factors along with increased levels of the relevant fractions of fulvic acids (FA-1 and FA-2; Leonidova and Bilanchyn, 2017, pp. 116 and 119) are responsible for such a high acidity of the island soils.

Another specific feature of the studied soils is unordinary law content or an absence of humus level of dark-brown humic acids bound with calcium (the HA-2 fraction), which are typical for chernozems. A very low concentration of this fraction (usually 1-2 to $3-4 \%$ ) has been only found in the upper humus accumulation horizons while it is absent in the layers downwards in the soil profile. In our opinion, it can be due to insignificant amount of calcium involved in the biochemical cycle on the island as this element is virtually absent in the rocks forming its surface. With increasing rate of the biological cycling of chemical elements and chernozem formation, the upper soil horizons are enriched with calcium of biogenic origin; the amount of calcium adsorbed to the soil colloidal complex increases considerably, which is a prerequisite for the formation of the HA-Ca fraction in humus.

The results obtained in the study of optical properties of humic substances indicate relatively high optical density of humic acids which is typical for the soils of chernozemic type. As reported by M. Kononova (1963), high optical density of humic acids in chernozems is an indicator of high condensation of aromatic nuclei and low levels of side radicals carrying hydrophilic groups in their molecules. It is clear that the conditions of soil formation on the island, in particular alternation of spring and early-summer moistening and summer-autumn dry weather, favour the formation of humic acids of fairly complex structure and composition in chernozems. The optical density factor for humic acids in soils with relatively higher water availability in the western and northern parts of the island is slightly higher as compared to relatively more xeromorphic chernozems in the eastern part of the island. The optical density factors of humic acids decrease downwards in the profiles of almost all examined chernozems. Absorption spectral curves also become steeper with increasing depth; that indicates to the increase in the abundance of brown humic acids which is the most likely associated with the acid paternal rocks or simplification of their molecules under conditions of alkalinity and salinity of soils. The value $\mathrm{E}^{0.001}$ in the upper horizons of the studied soils is 0.091-0.100, which gives grounds for their classification as southern chernozems with the signs of impact of acid soil-forming rocks, as well as alkalinity and salinity of soils (Kononova, 1963). This parameter of 
Table. Morphology, chemical composition and properties of the Zmiiny Island chernozems

\begin{tabular}{|c|c|c|c|c|c|c|c|c|c|c|c|c|}
\hline \multirow{3}{*}{ Profile, soil ${ }^{*}$} & \multirow{3}{*}{ 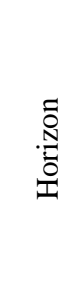 } & \multirow{3}{*}{ 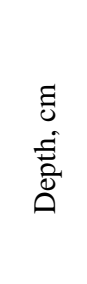 } & \multirow{3}{*}{ 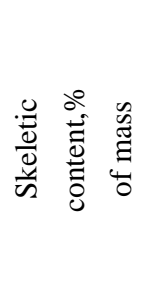 } & \multirow{2}{*}{$\begin{array}{c}\text { Phy- } \\
\text { si- } \\
\text { cal } \\
\text { clay }\end{array}$} & \multirow{2}{*}{$\begin{array}{l}\text { To- } \\
\text { tal } \\
\text { salts }\end{array}$} & \multicolumn{2}{|c|}{$\begin{array}{l}\text { Humus status } \\
\text { indicators }\end{array}$} & \multirow{3}{*}{$\frac{\mathrm{pH}_{\text {wat }}}{\mathrm{pH}_{\text {sol }}}$} & \multirow{2}{*}{$\begin{array}{l}\text { Hy- } \\
\text { drol. } \\
\text { acid- } \\
\text { ity }\end{array}$} & \multirow{2}{*}{$\begin{array}{c}\text { Total } \\
\text { absorbed } \\
\text { base } \\
\text { cations }\end{array}$} & \multirow{3}{*}{ 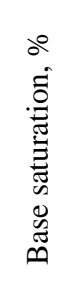 } & \multirow{3}{*}{$\begin{array}{l}\text { Exchange } \\
\mathrm{Na}^{+}, \%\end{array}$} \\
\hline & & & & & & $\begin{array}{l}\mathrm{Hu}- \\
\text { mus }\end{array}$ & \multirow{2}{*}{$\begin{array}{l}\mathrm{C}_{\mathrm{HA}} / \\
\mathrm{C}_{\mathrm{FA}}\end{array}$} & & & & & \\
\hline & & & & \multicolumn{3}{|c|}{$\begin{array}{l}\% \text { of the fine- } \\
\text { grained soil mass }\end{array}$} & & & \multicolumn{2}{|c|}{$\mathrm{mmol} \cdot \mathrm{eq} / 100 \mathrm{~g}$} & & \\
\hline \multicolumn{13}{|c|}{ Geomorphic-hypsometric level (zone) of inland high plateau and close slopes } \\
\hline \multirow{3}{*}{$\begin{array}{c}\text { O3-19, } \\
\mathrm{Ci}\end{array}$} & $\mathrm{Hq}$ & $5-15$ & 61.5 & 25.1 & 0.22 & 14.6 & 3.2 & $\frac{5.40}{4.95}$ & 13.13 & 35.50 & 73.0 & 3.38 \\
\hline & Hpq & $16-24$ & 73.6 & 28.3 & 0.39 & 14.6 & 3.3 & $\frac{4.95}{4.30}$ & 18.81 & 30.37 & 61.8 & 6.28 \\
\hline & Phq & $24-34$ & 76.9 & 32.2 & 0.72 & 10.9 & 3.5 & $\frac{4.30}{3.70}$ & 22.75 & 24.63 & 52.0 & 10.96 \\
\hline \multicolumn{13}{|c|}{ Geomorphic-hypsometric level (zone) of slopes with an angle up to $3-5^{\circ}$} \\
\hline \multirow{3}{*}{$\begin{array}{l}\text { O3-13, } \\
\text { east-facing } \\
\text { slope, } \\
\text { Ci }\end{array}$} & $\mathrm{Hq}$ & $4-14$ & 70.1 & 25.2 & 0.15 & 17.9 & 2.4 & $\frac{4.75}{3.80}$ & 24.06 & 23.30 & 49.2 & 3.56 \\
\hline & Hpq & $14-23$ & 85.8 & 25.1 & 0.15 & 15.1 & 2.5 & $\frac{4.15}{3.28}$ & 35.00 & 19.10 & 35.3 & 8.48 \\
\hline & Phq & $23-32$ & 81.0 & 26.7 & 0.14 & 8.5 & 2.5 & $\frac{4.26}{3.15}$ & 25.38 & 9.78 & 27.8 & 12.68 \\
\hline \multirow{2}{*}{$\begin{array}{c}\text { O3-16, } \\
\text { south-facing } \\
\text { slope, } \\
\text { Ci }\end{array}$} & $\mathrm{Hq}$ & $5-15$ & 61.8 & 23.0 & 0.15 & 13.4 & \multirow{2}{*}{$\mathrm{n} / \mathrm{d}$} & $\frac{4.93}{4.00}$ & 18.81 & 20.44 & 52.1 & 6.95 \\
\hline & Hpq & $17-24$ & 60.3 & 24.0 & 0.30 & 7.7 & & $\underline{4.13}$ & 22.75 & 11.34 & 33.3 & 7.76 \\
\hline \multirow{2}{*}{$\begin{array}{c}\text { O3-20, } \\
\text { north-facing } \\
\text { slope, } \\
\text { Cs }\end{array}$} & $\mathrm{Hq}$ & $9-19$ & 70.0 & 27.1 & 0.16 & 18.2 & 3.3 & $\frac{4.65}{3.72}$ & 28.44 & 21.12 & 42.6 & 7.95 \\
\hline & Hpq & $27-37$ & 58.0 & 28.5 & 0.13 & 14.7 & 2.7 & $\underline{\underline{4.56}}$ & 29.31 & 14.73 & 33.5 & 8.69 \\
\hline \multicolumn{13}{|c|}{ Geomorphic-hypsometric level (zone) of the diluvium-accumulative bottoms of the hillsides and bottomlands } \\
\hline \multirow{4}{*}{$\begin{array}{l}\text { O3-15, } \\
\text { bottom of } \\
\text { slope, } \\
\text { Cs }\end{array}$} & Htq & $7-17$ & 40.2 & 19.9 & 0.19 & 14.8 & 2.5 & $\frac{5.70}{4.75}$ & 11.81 & 27.20 & 69.7 & 7.32 \\
\hline & $\mathrm{Hq}$ & $20-30$ & 46.6 & 28.2 & 0.41 & 14.0 & 2.9 & $\frac{4.55}{3.85}$ & 22.31 & 20.77 & 48.2 & 5.58 \\
\hline & Hpq & $33-44$ & 52.5 & 19.2 & 0.50 & 12.8 & 3.0 & $\frac{4.40}{3.75}$ & 23.19 & 20.87 & 48.4 & 5.17 \\
\hline & Phq & $44-52$ & 34.0 & 38.1 & 0.53 & 5.0 & \multirow{4}{*}{$\mathrm{n} / \mathrm{d}$} & $\frac{4.26}{3.65}$ & 14.88 & 15.02 & 50.2 & 6.33 \\
\hline \multirow{3}{*}{$\begin{array}{l}\text { O3-17, } \\
\text { bottom of } \\
\text { slope, } \\
\text { Cs }\end{array}$} & $\mathrm{Hq}$ & $6-16$ & 39.5 & 22.5 & 0.09 & 10.5 & & $\frac{5.35}{4.25}$ & 15.75 & 19.08 & 54.8 & 3.51 \\
\hline & $\mathrm{Hpq}$ & $20-30$ & 47.6 & 26.3 & 0.15 & 7.0 & & $\underline{4.90}$ & 15.75 & 16.29 & 50.8 & 7.12 \\
\hline & Phq & $40-50$ & 44.0 & 35.5 & 0.14 & 4.1 & & $\underline{4.98}$ & 10.06 & 14.80 & 46.2 & 6.28 \\
\hline \multirow{4}{*}{$\begin{array}{l}\text { O3-21, } \\
\text { bottomland, } \\
\text { Cm }\end{array}$} & $\mathrm{H}$ & $6-15$ & 38.1 & 38.1 & 0.16 & 12.3 & 1.7 & $\frac{5.78}{4.85}$ & 10.94 & 34.41 & 75.9 & 4.74 \\
\hline & {$[\mathrm{H}]$} & $20-30$ & 56.1 & 35.2 & 0.11 & 13.4 & 2.2 & $\frac{5.50}{4.20}$ & 17.50 & 23.82 & 57.7 & 8.06 \\
\hline & {$[\mathrm{H}]$} & $40-50$ & 56.0 & 35.7 & 0.15 & 13.5 & 3.6 & $\frac{5.25}{3.86}$ & 24.94 & 22.92 & 47.9 & 13.66 \\
\hline & Hpqgl & $60-70$ & 65.0 & 40.9 & 0.09 & 5.9 & $\mathrm{n} / \mathrm{d}$ & $\frac{5.30}{3.85}$ & 13.13 & 15.46 & 54.1 & 13.78 \\
\hline
\end{tabular}

* Soil type indices: $\mathrm{Ci}$ - chernozemic immature soil; $\mathrm{Cs}$ - chernozemic shallow soil; $\mathrm{Cm}$ - meadow-southern-chernozemic warp soil. 
humus status of the island chernozems shows moderate to high values (Grishina and Orlov, 1978). The estimated values of the parameter are slightly higher for better moistened soils in the western and northern parts of the island with more favourable humusformation conditions. The values of the parameter are lower for the soils of more xeromorphic east-facing slopes; this indicates not only to just worse conditions for the humus formation, but also to the higher level of brown humic acids in humus. The highest values of $\mathrm{E}_{4}^{0.001}(0.10-0.11)$ have been detected in the buried hur mus horizon $\mathrm{H}$ of the meadow-southern-chernozem warp soil at the bottom of the depression wherein under conditions of optimal moistening the conditions of humus formation and formation of humic substances typical for chernozems are also optimal. All crosssections show this parameter decreasing with theprofile depth, which is likely due to increasing content of brown humic acids associated with either growing impact of acid soil-forming rocks or simplification of humic acid molecules under conditions of alkalinity and salinity of soils.

The results of the investigation of the conditions of chernozem formation on Zmiiny island, their quite specific material-and-chemical composition and properties, enables us to present some considerations with regard to the nature and specificity of the genesis of these soils and criteria for their diagnostics and classification. Extensive root system of the steppe herbaceous vegetation, and hence thick chernozems, can hardly be formed here over thin stony non-carbonate weathering crust. Under such conditions, gradual accumulation of organics on the surface occurs, which results in gradual thickening of the soil profile, increasing granulometric composition and water-holding capacity, as well as higher content of humus and biophile elements in the surface horizons.

While the lower part ofthe island chernozem profile inherits to a certain extent the properties of parental rocks, the impact of these rocks gradually decreases upwards in the profile with increasing influence of soil turf and humus accumulation processes. The properties of chernozems gradually enhance in the island soils: the content of absorbed bases increases markedly; the HA-2 fraction is formed in humus; the stoniness and acidity decrease, and water-physical properties enhance. According to V.V. Ponomariova and T.O. Plotnikova (1980), it is the soil turf and humus accumulation process under conditions of the steppe biome that is responsible for the formation of carbonate horizon in the soil profile and that ensures the stability of the soils of chernozemic type. In our opinion, the soil formation on Zmiiny Island is an irreversible and continuous process which leads to the enhancement of the chernozem properties and characteristics, and the existing cover of the steppe herbaceous vegetation facilitates this process to a great extent.

The afore-mentioned results of our many-year study of the Zmiiny Island chernozems and specificity of their genetic origin, in particular their morphology, material-and-chemical composition and especially their properties, enable us to draw some conclusions about justification of diagnostics and classification of these soils as chernozems. First of all, it should be noted that diagnostics and classification of soils are two main lines of activities of the soil science and they are usually conducted simultaneously when studying soils. The profile method is mainly used to perform soil diagnostics; it implies examination of features and properties of the soil profile directly related to the processes of its genesis, further evolution and economic development. In particular, these are such features (parameters) as stage of maturity and degree of differentiation of the soil profile; accumulation or depletion of certain compounds and elements; the extent of transformation or alteration of soil-forming rock - they all serve as grounds for assumptions with regard to genesis and evolutionary processes, their tendencies and soil-genetic effects. Upon the results of diagnostics, soils can be assigned to one or another classification taxonomic unit, which is grouping soils by the conditions and genesis processes, profile configuration, key properties, thickness and specific features of fertility.

As diagnostics of any soil, as noted above, involves predominantly the analyses of characteristics, features and properties of its profile, the classification of the island soils as chernozems can be considered as fair lawful. The island soil exhibits a profile of typical chernozem humus accumulation type with characteristic genetic horizons, which is shallow yet very gravelly and non-carbonate within the entire bulk. However, as early as in 1948 in the classic monograph "Russian Chernozem", V.V. Dokuchaev wrote about the possibility of formation of gravelly chernozems with shallow profile over dense rocks. He found out that chernozems were formed on the rocks of various types - loess, loess-like and light-clay loams, glacial and non-glacial clays, sandy- and clayloam, limestone and marlstone, clay slates and other dense rocks. However, the structure, composition and properties of chernozems differ significantly depending on the rock on which they were formed. The classification of the island soils as chernozems within the national system of soil classification as of 2005 (Polupan et al., 2005), which is based on the 
factor-genetic approach for the study and diagnostics of soils, is also justified.

Note that when classifying soils in accordance with the national classification system, it is necessary to specify additionally the lithological series assigned by the type and specific properties of the relevant soilforming rock. In this case, the classification definition of chernozem should be extended with additional description "over alluvia or alluvium-deluvium of dense siliceous rocks".

At the same time, it should be noted that one of the objectives of this study is to determine a niche for classification of the Zmiiny Island chernozems within the World Reference Base for Soil Resources (WRB) which is the current international standard of soil classification. WRB is a reference database with elements of the hierarchy with certain formal boundaries (Polchina and Nichorich, 2006; World Reference Base for Soil Resources 2014. International soil classification system for naming soils and creating legends for soil maps, 2014). The WRBclassification is based on the substantive-genetic approach which employs a set of diagnostic horizons, properties and features of soils with clearly determined quantitative limits of the relevant parameters. The structure of WRB is two-level and non-hierarchical. The first level refers to reference groups of soils. The groups are clearly and formally separated from each other. At the second level of classification, the soil name is revised by adding the so-called qualifiers and specifiers for further extension of specification (Ivanyuk, 2017).

Thus, let us try to determine the position of the Zmiiny Island chernozems formed on dense acid rocks beneath the steppe herbaceous vegetation in the WRB classification system. According to the WRB classification, these are only soils that are formed on high-porous rocks (usually loess) beneath vegetation rich in grasses in the areas experiencing continental climate with cold winter and hot summer that can be classified as chernozems. Such soils are characterised by high humus content, neutral or nearly neutral reaction, and a carbonate (carbonate-accumulative) horizon which can be easily distinguished in their profile. Apparently, the island soils have specific genetic origin and differ distinctly from the classical chernozems as specified in the WRB system. These soils are shallow, gravelly-and-stony, not-carbonate throughout the entire bulk, acid, rich in humus of specific composition. Thus, it would be justified to assign these soils to the reference group of Phaeozem soils in the WRB system. According to Polchina and Nichorich (2006), phaeosems are soils of tall-grass steppe with moderate continental climate; they tend to be not-carbonate in their top layer of one-metre depth. Their profile is characterised by the presence of the surface mollic horizon of dark-brown to black colour, enriched with humus.

At the second level, qualifiers can be highlighted. The following qualifiers are characteristic for the island soil: Leptic as there are solid rocks within $100 \mathrm{~cm}$ from the soil surface; and Skeletic as it contains more than $40 \%$ (within the bulk) of coarsegrained fragments to a depth of more than $100 \mathrm{~cm}$ from the mineral surface of the soil. To revise the qualifier name, a specifier should be used. In this case, the specifiers Epi and Endo, which indicate the depth of the bedrock, are used to specify the Leptic qualifier. Therefore, we suggest classifying immature and shallow chernozemic soils of Zmiiny Island as Epileptic Phaeozem (Skeletic) and Endoleptic Phaeozem (Skeletic), respectively.

\section{Conclusions}

1. The Zmiiny Island chernozems have a specific genetic origin and are formed over shallow (usually $25-40 \mathrm{~cm}$, up to $50 \mathrm{~cm}$ of depth) rocky-gravel weathering crust of dense acid rocks beneath the cover of substantially intact steppe herbaceous vegetation given the all year round supply of mineral salts, mainly sodium chlorides and sulphates. About $60-70 \%$ of the grass biomass is concentrated in the soil turf horizon $\mathrm{Hd}$ and the ground layer of the steppe litter mat Hc, which are able to retain moisture and, to a certain extent, readily soluble salts from atmospheric precipitation.

2. The morphology, material-and-chemical composition and some other properties of the island chernozems can be characterised by a number of distinctive features. These chernozems are shallow, gravelly and stony, not-carbonate, practically unstructured, acid, salinized to a different extent (from 0.15-0.20to $0.30-0.40 \%$ ), alkali (with Na content from 4-8 to 11$13 \%$ ) yet without solonets-illuvial differentiated profile. The humus content in the upper soil horizons is very high (10-12 to $15-18 \%)$ with the humic to fulvic acid ratio $\mathrm{C}_{\mathrm{HA}} / \mathrm{C}_{\mathrm{FA}}=2.5-3.3$ which is typical for chernozems. However, the HA-1 fraction dominates in the humus $(65-75 \%$ in the upper horizons and $80-84 \%$ in the lower ones) while the level of typical chernozem fraction HA-2 is very low (1-2 to 3-4\%) or is absent.

3. It has been suggested classifying immature and shallow chernozems of Zmiiny Island in accordance with the World Reference Base for Soil Resources (WRB) as Epileptic Phaeozem (Skeletic) and Endoleptic Phaeozem (Skeletic), respectively. 


\section{References}

Bilanchyn, Y. M., Zhantalay, P. I., Tortyk, M. Y., Buyanovskiy, A. O., 2008. Doslidzhennia gruntovoho pokryvu o. Zmiinyy. [Studies of the Zmiinyi island soil cover]. Ostriv Zmiinyy. Abiotychni kharakterystyky: monohrafiia [Zmiinyi island. Abiotic characteristics: monograph]. Astroprint, Odessa (in Ukrainian).

Bilanchin, Y. M., Goshurenko, L. M., Sviderska, I. V., 2009. Pro henetychnu pryrodu chornozemiv o. Zmiyinyy, yikh rechovynno-khimichnoho skladu i vlastyvostey [Genetic nature of Zmiiny island chornozems, nature of their peculiarities and substantive and chemical composition]. Visn. Odesa National Univ. Ser. Geograph. Geol. 14 (1), 240-245 (in Ukrainian).

Bilanchin, Y. M., 2011. Chornozemni grunty ostrova Zmiinyi [ChornozemsoilsofZmiinyisland]. Agrochemistry and soil science. 76, 95-100 (in Ukrainian).

Bilanchyn, Y. M., Zhantalay, P. I., Tortyk, M. Y., Buyanovskiy, A. O., Sviderska, I. V., 2010. Kartohrafuvannya gruntovoho pokryvu i stvorennya gruntovoyi karty ostrova [Soil layers mapping and soil map creation of the Zmiiny island], Agrochemistry and Soil Science. Collected papers.Special Edition.Book 2.Soil science. Zhytomer, 10-12. (in Ukrainian).

Bilanchyn, Y.M., Medinets, V.I., Goshurenko, L. M., Pitsy, V.Z., 2013. Atmosferni opady i vidkladennia ta vody pidgruntovoho stoku ostrova Zmiinyi [Atmospheric precipitation, atmospheric sediments, and subsoil runoff on Zmiiny island]. Visn. Odesa National Univ. Ser. Geograph. Geol. 18 (17), 116-132 (in Ukrainian).

Charzynski, P., 2006. Testing WRB on Polish Soils. Torun.

Dokuchaev, V. V., 1948. Russkij chernozem: Otchet Vol'n. jekon. [Russian chornozems: Report of free economist]. Selkhozgiz, Moscow (in Russian).

Grishina, L. A., Orlov, D. S., 1978.Sistema pokazatelej gumusnogo sostojanija pochv[The system of indices of a humus soil state. Problems of soil science]. Nauka, Moscow (in Russian).

Ivanyuk, G. S., 2017.Klasyfikatsiia i diahnostyka gruntiv: navch. posibnyk [Classification and diagnostics of soils]. LNU named after Ivan Franko, Lviv (in Ukrainian).

Ivanyuk, H. S., 2016. Svitovoi referatyvnoi bazy gruntovykh resursiv (WRB) vid stvorennia do sohodennia [Worold reference base for soil resources (WRB): from the establishment to the present time]. Visn. Odesa National Univ. Ser. Geograph. Geol. 21 (1), 78-84 (in Ukrainian).

Kononova, M. M., 1963.Orhanycheskoe veshchestvo pochvы, eho pryroda, svoistva y metodы yzuchenyia [Organic matter of soil, its nature, properties and methods of study]. Publishing- house of the USSR Academy of Sciences, Moscow (in Russian).

Krasilnikov, P. V., 2009. A Handbook of Soil Terminology, Correlation and Classifi cation. Earthscan, London.

Leonidova, I. V., 2013. Biolohichnyi chynnyk gruntotvorennia ostrova Zmiinyi [Biological factor of soil formation of Zmiiny island].Visn. Odesa National Univ. Ser. Geograph. Geol. 18 (17), 133 146(in Ukrainian).

Leonidova, I. V., 2017. Osoblyvosti protsesu chornozemoutvorennia na ostrovi Zmiinyi [Peculiar features of the Black soil formation processes onZmiiny island].Visn. Odesa National Univ. Ser. Geograph. Geol.22 (30), 102-112 (in Ukrainian).

Leonidova, I. V., Bilanchyn, Y. M., 2017.Heohrafohenetychni osoblyvosti gruntotvorennia na ostrovi Zmiinyi: monohrafiia [Geographic and genetic peculiarities of soil formation on Zmiiny island]. ONU named after I. I. Mechnikov,Odesa (in Ukrainian).

Manyuk, V., 2004. Geoscientific significance and tourist values of Zmeynyi (Snake) island.Proceeding of the Conference Geological heritage concept, conservation and protection policy in Central Europe. Polish Geological Institute Special Papers. Cracow-Warzawa, 155-161.

Polchina, S.M., Nichorich, V.A., 2006. Svitova referatyvna baza gruntovykh resursiv 2006.Struktura dlia mizhnarodnoi klasyfikatsii, koreliatsii ta komunikatsii [World reference base of soil resources 2006.Structure for international classification, correlation and communication]. Ruta, Chernivtsi (in Ukrainian).

Polchina, S. M., 2005. Koreliatsiia nomenklatury pryrodnykh gruntiv Ukrainy ta FAO/WRB [Correlation of Ukraine's natural soil nomenclature and FAO / WRB].Visn.University Univ. Ser. Biology.252, 214-220 (in Ukrainian).

Polupan, M.I., Solovey, V.B., Velichko, V. A., 2005. Klasyfikatsiia gruntiv Ukrainy [Classification of soils of Ukraine].Agrarian Science, Kyiv (in Ukrainian).

Ponomariova, V. V., Plotnikova, T. A., 1980. Gumus i pochvoobrazovanie (metody i rezul'taty izuchenija) [Humus and soil formation (research methods and results)]. Nauka, Moscow (in Russian).

Romanova, T. A., 2004. Diagnostika pochv Belarusi i ih klassifikacija $\mathrm{v}$ sisteme FAO-WRB.Minsk (in Russian).

Stolbovoj, V.S., Sheremet, B.V., 2000. Korreljacija legend pochvennoj karty SSSR masshtaba 1:2500000i pochvennoj karty mira FAO [Correlation of the legend of the soil map of the USSR in scale 1:2500000 and FAO soil map of the world]. Soil science.3, 277-287 (in Russian).

World Reference Base for Soil Resources 2014. International soil classification system for naming soils andcreating legends for soil maps, 2014.World Soil Resources Reports. 106. FAO. Rome. 